\title{
Legislação, educação e política: percepções sociais sobre a Lei de Diretrizes e Bases e o Plano Nacional de Educação (20 I I-2020)'
}

Antonio Teixeira de Barros ${ }^{2}$ Lúcio Meireles Martins ${ }^{3}$

"Nossa esperança está pendente sempre do novo que cada geração aporta." (Hannah Arendt, Entre o passado e o futuro).

\section{Resumo}

Neste texto, estuda-se a relação educação/legislação, na perspectiva da Sociologia Política, com base nas percepções de cidadãos sobre a Lei de Diretrizes e Bases da Educação Nacional (LDB) e o Plano Nacional de Educação (PNE) (201 I-2020), a partir das seguintes questões: qual o grau de conhecimento da população sobre a LDB em seus 15 anos de vigência? Qual o nível de interesse do público sobre o PNE e quais suas expectativas? A metodologia consiste na técnica de survey, com aplicação de questionário com amostragem nacional de 1.010 informantes, além de pesquisa bibliográfica e documental. O escopo teórico é focado na sociologia política weberiana, na qual educação e legislação são vistas como resultantes históricas da racionalização ocidental. Os dados indicam pouco interesse popular pela LDB e pelo PNE. Entretanto, a variável escolaridade eleva o nível de conhecimento/interesse. O tema é reconhecido como nacionalmente relevante, mas a conotação política é pouco destacada, sobretudo quando se trata da função do Poder

As opiniões expressas no texto são de inteira responsabilidade dos autores.

2 Doutor em Sociologia pela Universidade de Brasilia (UnB), Brasilia, Distrito Federal, Brasil. Docente e Pesquisador do Programa de Mestrado em Ciência Política do Centro de Formação da Câmara dos Deputados (Cefor). vinculado à linha de pesquisa Educação e Comunicação para a Democracia. E-mail: antonibarros@gmail.com.

3 Graduado em Comunicação Social - Relações Públicas pela Universidade Estadual de Londrina (UEL), Londrina, Paraná, Brasil. Pesquisador do Programa de Pós-Graduação do Centro de Formação da Câmara dos Deputados (Cefor), vinculado à linha de pesquisa Educação e Comunicação para a Democracia E-mail: luciogoiano@hotmail.com. 
Legislativo no debate sobre políticas educacionais. O papel do Legislativo é associado à garantia/ fiscalização de recursos.

Palavras-chave: Educação, legislação e política. Políticas públicas educacionais. Parlamento, sociedade e educação. Educação e política.

\section{Introdução}

O escopo da relação entre os temas pertinentes ao campo educacional e a esfera de competência do Poder Legislativo é amplo, ambíguo e complexo, ou seja, trata-se de um assunto difícil de ser caracterizado no curto espaço de um artigo. Por esse motivo, destacaremos alguns dos aspectos mais relevantes, embora sucintamente, iniciando pela abordagem institucional desenhada nas últimas décadas. No Brasil, até o final da década de 1980, a relação entre educação e o Poder Legislativo se limitava à organização do sistema escolar por meio da legislaçáo (COSSON, 2008; MARQUES JR., 2009), com um fórum parlamentar específico, ou seja, a comissão temática responsável pelo assunto, com uma agenda de longos anos de discussáo (nem sempre continuada). No caso da Lei de Diretrizes e Bases da Educaçáo Nacional de 1961 (Lei Federal no 4.024), foram 13 anos de tramitação. Isso pode resultar de vários fatores, como a complexidade dos temas e as dificuldades inerentes ao ambiente político. A lentidão, contudo, pode levar a população a achar que o assunto não recebe a devida atenção dos parlamentares.

Devido a uma tendência internacional de valorização da educação para a democracia e a cidadania (COSSON, 2008) e também como provável tentativa dos parlamentos de responder à crise generalizada de falta de confiança da sociedade (RIBEIRO, 2011), a educaçáo passou a ser tratada de forma diferenciada nos últimos anos pelo Congresso Nacional brasileiro, o que resultou em várias iniciativas avaliadas como relevantes e positivas, tais como a definiçáo de mecanismos de financiamento e de avaliação da educação pública, o que representa um marco na consolidaçáo do tema como política pública com a participação do Poder Legislativo como protagonista (MARTINS, 2011). ${ }^{4}$

4 No âmbito do financiamento público, o autor destaca o Fundo de Manutenção e Desenvolvimento da Educação Básica e de Valorização dos Profissionais da Educação (Fundeb), que atende toda a educação básica, da creche ao ensino médio. Substituto do Fundo de Manutenção e Desenvolvimento do Ensino Fundamental e de Valorização do Magistério (Fundef), que vigorou de 1997 a 2006, o Fundeb está em vigor desde janeiro de 2007 e se estenderá até 2020. Já no campo da avaliação, destaca-se o Exame Nacional do Ensino Médio 
Em 20 de dezembro de 2011, a Lei de Diretrizes e Bases da Educaçáo (Lei Federal no 9.394/1996) completou 15 anos de vigência. Trata-se de um marco na história da educaçáo brasileira e momento oportuno, portanto, para uma reflexáo sobre o papel da instruçáo pública nesse período e o legado histórico da legislaçáo que regulamenta o setor, o que inclui a Lei de Diretrizes e Bases da Educação Nacional (LDB) e o Plano Nacional de Educaçáo (PNE). Por essa razáo, a Câmara realizou uma pesquisa de opiniáo pública sobre o assunto no final do ano de 2011, quando a LDB completou 15 anos de vigência. O objetivo do texto, portanto, é analisar as percepçóes do público sobre a atuação do Parlamento, com foco específico na LDB e no debate legislativo sobre o PNE. O problema de pesquisa é composto pelas seguintes questóes: (1) como o Poder Legislativo pode contribuir para aperfeiçoar o ensino público? (2) qual o grau de conhecimento da população sobre o conteúdo e as contribuiçóes da LDB ao longo dos seus 15 anos de vigência? (3) qual o nível de informação do público sobre o PNE em discussáo na Câmara e quais as expectativas da sociedade em torno do plano?

Os dados expressam a opinião da populaçáo das cinco regióes geográficas brasileiras e apresentam, em linhas gerais, as tendências mais expressivas da opiniáo dos cidadáos ouvidos durante a sondagem. A coleta de dados foi realizada por telefone, por meio de questionário estruturado, com perguntas fechadas. No total foram ouvidas 1.010 pessoas. Os parâmetros quantitativos da amostra foram definidos de acordo com a distribuiçáo populacional nas cinco regióes, conforme dados do último censo do Instituto Brasileiro de Geografia e Estatística (IBGE), de modo a contemplar uma amostragem equilibrada da população, segundo o perfil demográfico regional. A sondagem de opinião foi conduzida pela Secretaria de Comunicaçáo da Câmara dos Deputados, no segundo semestre do ano de 2011, com o objetivo de avaliar as percepçóes da sociedade sobre a LDB e o PNE. ${ }^{5}$

Do ponto de vista metodológico, o estudo dialoga com as principais tendências das pesquisas sobre educaçáo, no que se refere às interconexóes entre

(Enem) e o Exame Nacional de Desempenho de Estudantes (Enade), que integra o Sistema Nacional de Avaliação da Educação Superior (Sinaes).

5 O levantamento foi realizado por uma empresa terceirizada, mediante contrato relativo às atividades da Central de Atendimento ao Cidadão (Serviço 0800 de atendimento telefônico gratuito), sob a supervisão e acompanhamento dos pesquisadores. 
pesquisa qualitativa e pesquisa quantitativa e às possibilidades de problematização de dados empíricos para estudos avaliativos (BOGDAN; BIKLEM, 1982; LÜDKE, 1988; LANGEMAN; SHULMAN, 1999; ANDRÉ, 2001). Antes da análise dos dados, a título de contextualização histórico-política e teórica, o texto apresenta um breve panorama sobre a evolução da trajetória do Poder Legislativo no âmbito de sua atuação no campo da educaçáo, além de discutir, do ponto de vista teórico, a relação entre educação e política, sob a perspectiva da sociologia política weberiana, que associa legislação e educaçáo ao âmbito do desenvolvimento da racionalizaçáo das sociedades ocidentais.

\section{Breve contextualização da educação no Brasil pela perspectiva da legislação}

A história política da educaçáo brasileira possui períodos bastante característicos marcados pela atuaçáo de diferentes instituiçóes mantenedoras e variados objetivos, iniciando com o período jesuítico (1549-1759), cujo objetivo principal era a alfabetização dos índios, sua doutrinação para a fé católica e para o trabalho. O fim desse período ocorreu com a expulsáo dos jesuítas (1759) pelo Marquês de Pombal e o consequente fim do sistema de ensino jesuítico. A educaçáo passou a ser de responsabilidade dos vice-reis nomeados por Portugal, porém, até a transferência da corte para o Brasil, "a educaçáo estava à deriva” (ARANHA, 1996, p. 135). Em 1772, a Coroa Portuguesa instituiu a primeira fonte de recursos para o financiamento da educação brasileira, o imposto denominado subsídio literário, que incidia sobre a carne verde, o vinho, o vinagre e a aguardente. O período Pombalino vai de 1760 a 1808, sendo que, a partir de 1808 até 1821, denominou-se período Joanino, devido à importância da atuaçáo de Dom Joáo VI na criação de instituições de ensino e cursos em diversas áreas do conhecimento, especialmente no Rio de Janeiro. Nesse período, o foco do ensino estava em gerar conhecimentos técnicos e artísticos necessários à nobreza (ALMEIDA, 1989).

Em termos legais, uma das mais importantes evoluçóes na educação brasileira, anteriormente à República, aconteceu no período imperial (1822 a 1888), especificamente em 1824, quando a primeira constituição brasileira, outorgada por Dom Pedro I, estabeleceu a intençáo de instruçáo primária gratuita a todos os cidadáos e o princípio da liberdade de ensino. Em 1827, a única lei sobre educação com repercussáo nacional elaborada em mais de um 
século determinou a criação de escolas de primeiras letras em todas as cidades, vilas e vilarejos e "escolas de meninas nas cidades e vilas mais populosas" (ARANHA, 1996, p. 152). A educação feminina era restrita às habilidades de ler, escrever, bordar e costurar. Em 1854, o Decreto no 1.331 -A promoveu a reforma dos ensinos primário e secundário, exigindo professores credenciados e a volta da fiscalizaçáo oficial. Com essa finalidade, criou-se a Inspetoria Geral da Instrução Primária e Secundária.

A partir da Proclamação da República, instituiu-se o ensino laico nas escolas públicas, em oposição ao ensino religioso, por meio da Constituiçáo de 1891 . Nesse período, também foi criado o Ministério da Instrução, Correios e Telégrafos. A partir de 1824, com a instituiçáo da liberdade de ensino, ganharam espaço os colégios particulares vinculados principalmente à igreja católica (BRIQUET, 1946). Essa tendência típica do século XIX no Brasil foi oposta ao resto do mundo, cuja laicizaçáo se acentuava. Os poucos liceus provinciais fundados pela iniciativa pública foram desorganizados e enfrentaram falta de recursos, com professores mal habilitados e o ensino público ainda incipiente (ARANHA, 1996).

A Segunda República (1930-1936) foi marcada pela criação do Ministério da Educação e Saúde Pública e do Conselho Nacional de Educaçáo e pela implementação de reformas que reestruturaram as universidades, o ensino secundário e o ensino comercial (SAVIANI, 2001, 2007). Pela primeira vez, houve um plano nacional de organização da educação (ROMANELLI, 1978; XAVIER; NORONHA; RIBEIRO, 1994). A Constituiçáo de 1934 instituiu a educaçáo como direito de todos, devendo ser ministrada pela família e pelos poderes públicos, porém poucos anos depois, já no Estado Novo, a Constituiçáo outorgada em 1937 retrocedeu e retirou do texto esse direito. Entretanto, enfatizou o ensino pré-vocacional e profissional. Com essa perspectiva, a Reforma Capanema de 1942 reestruturou o ensino industrial e o ensino comercial e criou o Serviço Nacional de Aprendizagem Industrial (Senai).

Na República Nova, com a promulgação da Constituição de 1946, o país se redemocratizou e o direito à educação passou a ser também um dever, pois instituiu-se a obrigatoriedade de se cumprir o ensino primário e dar competência à União para legislar sobre as diretrizes e bases da educaçáo nacional. Essa constituição estabeleceu empenho mínimo de $10 \%$ do orçamento da Uniáo e $20 \%$ do orçamento de estados e municípios no setor. Após 13 anos 
de debates, em 1961 foi aprovada a Lei Federal no 2.024/1961, considerada a primeira LDB (Lei de Diretrizes e Bases da Educação Nacional), conforme registra a literatura especializada (ADRIÁO; OLIVEIRA, 2001; FONTOURA, 1968; VILALOBOS, 1969). A lei ampliou para 12\% o investimento em educação pela Uniáo e manteve o percentual dos estados e municípios. Entre os esforços do Estado nessa área, pós-golpe militar, destacou-se o Movimento Brasileiro pela Alfabetizaçáo (Mobral), que promoveu a instruçáo de jovens e adultos no período de 1967 a 1985, em substituição a outras campanhas, com o foco em treinamento de leitura e escrita, para formar mão de obra necessária à industrializaçáo crescente.

A segunda LDB (Lei Federal no 5.692/1971) manteve a participaçáo do Executivo Federal no financiamento da educaçáo e criou novas especificaçóes para a destinação dos recursos nos municípios, no sentido de ampliar a responsabilidade desses entes federados no ensino de $1^{\circ}$ grau (conforme nomenclatura da época). Essa lei incluiu no currículo do $1^{\circ}$ e $2^{\circ}$ graus a disciplina Educaçáo Moral e Cívica e reduziu a carga horária das disciplinas de Geografia e História, além da exclusáo de Filosofia, mas manteve o Ensino Religioso facultativo nas escolas públicas, conforme já previsto na primeira LDB. O período letivo foi ampliado de 180 para duzentos dias, e tornou-se obrigatória a matrícula no ensino de $1^{\mathrm{o}}$ grau ( $1^{\mathrm{a}}$ a $8^{\mathrm{a}}$ séries). Conforme nos apresenta Aranha, o ensino médio passa a ter a funçáo de profissionalização, porém os recursos materiais e humanos investidos do ensino público não possibilitaram que a obrigatoriedade dos oito anos de estudo primário e a profissionalização se efetivassem. Esse fato é confirmado pela promulgação da Lei Federal no 7.044/1982, que dispensou as escolas da obrigatoriedade da profissionalizaçáo, sendo retomada a ênfase na formação geral, já no contexto político da redemocratização.

A terceira LDB (Lei Federal no 9.394/1996), concebida sob as influências políticas que sucederam a Constituiçáo de 1988, aumentou o valor dos investimentos da Uniáo de $12 \%$ para $18 \%$ do orçamento. Para os estados e municípios, o percentual mínimo de investimentos passou para $25 \%$ de suas respectivas receitas. Também denominada Lei Darcy Ribeiro e Carta Magna da Educaçáo, foi a mais abrangente e de maior impacto em todos os níveis da educação nacional. Instituiu a gestáo democrática do ensino público e estabeleceu um núcleo comum para o currículo do ensino fundamental e médio e uma parte diversificada em função das peculiaridades locais e regionais. Essa 
LDB incluiu o ensino de Sociologia e Filosofia como conteúdos interdisciplinares, o que foi alterado para ensino obrigatório, com disciplinas específicas nas três séries do ensino médio, por meio de um projeto de lei aprovado no Congresso Nacional, em 2008 (PL no 11.684/2008).

Em 1996, o Ministério da Educaçáo criou o Fundo de Manutençáo e Desenvolvimento do Ensino Fundamental e de Valorizaçáo do Magistério (Fundef), que vigorou até 2006, quando foi substituído pelo Fundo de Manutençáo e Desenvolvimento da Educaçáo Básica e de Valorizaçáo dos Profissionais da Educaçáo (Fundeb). ${ }^{6}$ Trata-se de dois instrumentos legais que formulam e regulamentam os mecanismos de financiamento da educaçáo, sem, contudo, estabelecer critérios relativos à qualidade do ensino, conforme alerta Oliveira (2000, 2001). Por outro lado, esses instrumentos são apontados como um avanço no pacto federativo relacionado à educação (PINTO, 2007).

A LDB de 1996 redefiniu o sistema educacional brasileiro em todos os níveis: da creche às universidades, além de todas as outras modalidades de ensino, educaçáo especial, profissional, indígena, no campo e o ensino a distância. A instituiçáo de critérios para a formaçáo dos profissionais da educaçáo básica também foi objeto dessa norma. Na LDB está instituído o PNE, com dez anos de duraçáo. O primeiro foi aprovado pelo Congresso Nacional em 2001. O PNE possui metas ambiciosas, sendo que poucas delas foram atendidas completamente (além do atraso), como a instituiçáo de um piso salarial nacional do magistério, planejado para 2001 e legalmente validado apenas em 2011, após decisáo do Supremo Tribunal Federal. ${ }^{7}$ Outro ponto atendido foi a melhoria de sistemas de informaçáo e avaliaçáo da educaçáo, viabilizado pelo Sistema Nacional de Avaliação da Educaçáo Básica (Saeb), pela Prova Brasil e pelo desenvolvimento do Índice de Desenvolvimento da Educaçáo Básica (Ideb), que reúne esses dados como forma de acompanhamento.

A meta de ampliar o ensino fundamental de oito para nove anos também foi cumprida. Porém, diversas metas náo foram atendidas em sua plenitude e

6 Na impossibilidade de apresentarmos um levantamento completo sobre a legislação que rege a educação brasileira, incluimos aqui apenas alguns aspectos. Para mais informações, consultar: <http://www.fnde.gov. br/financiamento/fundeb/fundeb-legislacaos.

7 Esclarecemos que o artigo não tem o objetivo de realizar um balanço crítico das metas do PNE nem problematizar seus resultados. Apresentamos tão somente uma breve descrição dessas metas, uma vez que o estudo analisa as percepções da sociedade sobre o PNE, em termos mais amplos, sem focar metas especificas. 
tiveram resultados muito abaixo dos pretendidos, como a universalizaçáo do ensino fundamental, investimento de $7 \%$ do Produto Interno Bruto (PIB) em educaçáo (em 2010, o gasto foi de 4,3\% do PIB na faixa etária de quatro a 17 anos), ${ }^{8}$ ampliaçáo da educaçáo de jovens e adultos, redução de repetência e evasáo escolar, erradicaçáo do analfabetismo e ampliaçáo do atendimento na educaçáo infantil para crianças de três a cinco anos. Neste último quesito, a meta era de atendimento de $50 \%$ das crianças de até três anos e de $80 \%$ das de quatro e cinco anos, porém, conforme o balanço realizado em 2008 pelo Instituto Nacional de Estudos e Pesquisas Educacionais Anísio Teixeira (Inep), apenas $17,1 \%$ das crianças de até três anos tinham atendimento; já entre quatro e cinco anos, $77,4 \%$ estavam na pré-escola. Dados recentes levantados pela organizaçáo não governamental Todos pela Educação ${ }^{9}$ indicam que, em 2011, o percentual de crianças de quatro e cinco anos na pré-escola era de $80,1 \%$, ou seja, foi cumprida a meta estabelecida em 2001 para a pré-escola, porém a disponibilização da educaçáo infantil até os quatro anos de idade ainda representa um grande desafio a todas as instâncias de governo.

Outro marco da legislaçáo sobre educaçáo foi a aprovaçáo do Programa Nacional de Acesso ao Ensino Técnico e Emprego (Pronatec - Lei Federal $\mathrm{n}^{\circ} 12.513 / 2011$ ), que visa profissionalizar alunos de nível médio de todo o país, atendendo às crescentes necessidades de máo de obra especializada, demanda gerada pelo desenvolvimento socioeconômico por que passa o Brasil nas últimas décadas.

O PNE para o decênio 2011-2020 está contemplado no Projeto de Lei no 8.035/2010, que teve tramitaçáo iniciada na Câmara dos Deputados em 2010, sendo esta uma das motivaçóes para este estudo, além dos 15 anos da LDB vigente. As propostas do PNE 2011-2020 apresentadas pelo Governo Federal possuem algumas linhas centrais, a exemplo da universalizaçáo do acesso à educaçáo em certas faixas etárias, como a de quatro e cinco anos e 15 a 17 anos, bem como a alfabetizaçáo de todas as crianças de até oito anos. ${ }^{10}$

8 Dados quantitativos da educação brasileira disponiveis em: <http://www.todospelaeducacao.org.br/educacao-no-brasil/numeros-do-brasil/brasil/>.

9 Idem nota 1.

10 Diferentemente do PNE anterior, esta proposta apresenta uma quantificação pretendida que aparenta ser factível. Isso fica evidente na meta I, ao planejar que a educação infantil da população com até três anos chegue a 50\% desse público, e na meta 6, que prevê a educação integral implantada também na metade das escolas 
A educação profissional, que teve na aprovação do Pronatec um grande impulso, está delineada para dobrar seu número de matrículas vinculadas ao ensino médio. O tema da qualidade da educação, um dos principais motes do marketing político na campanha presidencial de 2010, está apresentado em diferentes perspectivas, sendo uma delas a melhoria do Ideb, que atualmente varia de 2,7 a 5 pontos, para 6 pontos nos anos iniciais do ensino fundamental; 5,5 nos anos finais e 5,2 no ensino médio; outra melhoria da qualidade será buscada pela ampliação da capacitação dos professores em todos os níveis de ensino, incluindo o ensino superior. A proposta do governo visa que $50 \%$ da população de 18 a 24 anos se matricule no ensino superior e que $33 \%$ ao menos concluam esse nível de ensino.

Nessa mesma perspectiva da qualidade da educação, o PNE em discussão pretende garantir que, nos próximos dois anos, todos os profissionais do magistério no país tenham planos de carreira e que o rendimento médio desses profissionais com mais de 11 anos de escolaridade seja equivalente ao rendimento de profissionais em outras carreiras com escolaridade equivalente. A gestáo escolar está contemplada apenas na meta 19, que visa garantir, mediante lei dos estados, Distrito Federal e municípios, a nomeação comissionada de diretores de escola a partir de critérios técnicos de mérito e desempenho e a participação da comunidade escolar. A meta 20 do PNE para o decênio 2011-2020, e a que possibilitará grande parte da execução das demais, é a ampliaçáo progressiva do investimento público, para o mínimo de $7 \%$ do PIB do país. A efetivação desse critério para o financiamento pretendido no primeiro PNE (2001-2010) tem sido o ponto de maior embate no Parlamento, já que entidades sindicais de professores e o movimento estudantil reivindicam $10 \%$ como referência.

Destaca-se que o projeto de lei está em tramitaçáo. Dessa forma, neste artigo, analisa-se a proposta apresentada pelo Poder Executivo, em 20 de dezembro de 2010. Foram excluídas dessa análise as milhares de emendas parlamentares que, ao final da tramitação pelo Congresso Nacional, poderão alterar significativamente o PNE que está em discussão pelos parlamentares.

públicas de educação básica de todo o país até 2020. Outro objetivo exposto na proposta do PNE em tramitação é a elevação da escolaridade média da população, buscando-se um mínimo de 12 anos de estudo para a população de 18 a 24 anos e a ampliação da alfabetização de adultos, com a erradicação do analfabetismo absoluto em certas faixas etárias e a redução drástica do analfabetismo funcional, além de integrar ao menos $25 \%$ desses adultos matriculados nos anos finais do ensino fundamental e ensino médio à educação profissional. 


\section{A lei como fator de coesão social e sua dimensão sociopolítica e educativa}

Do ponto de vista do pensamento filosófico, social e político, a legislação é vista como resultado do desenvolvimento da racionalidade moral das sociedades ocidentais, a partir da formalizaçáo dos costumes (mores) como elementos normativos de coesão, mas também de coerçáo social. A origem está no estudo da Filosofia Moral, visto que o termo "moral" deriva do latim mores, isto é, relativo aos costumes. Hannah Arendt, que foi influenciada pela Filosofia Moral alemá, especialmente de Kant, apresenta a diferença e os paralelos entre duas tradiçóes que se estabeleceram no pensamento ocidental acerca do significado filosófico e político da lei, sob esse enquadramento analítico. ${ }^{11}$ A primeira é originária do contexto político e cultural romano como decorrência da relaçáo contratual de pactos, alianças e acordos realizados após uma guerra, nos termos de uma ligaçáo duradoura, a fim de assegurar a paz, o comércio próspero e as trocas econômicas justas. Mas também é vista como mecanismo de ligaçáo entre os próprios cidadáos habitantes da mesma cidade, reino ou império. Dessa concepção se originou o termo lex (ligação), ou seja, "uma lei é algo que liga os homens entre si e se realiza não através de um ato de força ou de ditado, mas através de um arranjo ou um acordo mútuo" (ARENDT, 2004 , p. 112). Como se trata de um acordo mútuo, o estabelecimento de uma lei pressupóe a concordância de ambas as partes envolvidas e resulta de um consenso construído pelas duas partes. Nessa visáo, a lei é resultante de um processo dialógico e discursivo (lexis).

Nessa perspectiva de ligação, a lei constitui um recurso moral para evitar situaçóes de anomia social, na terminologia de Durkheim (2002), outro autor que argumenta de modo similar ao de Arendt, ao ressaltar que as leis e as normas sociais funcionam como "cimento social", ou seja, como agentes de coesão entre os indivíduos e as instituiçóes e, por extensão, entre a sociedade e o Estado. Mas, para que isso ocorra, segundo Durkheim, é necessário que haja desiderabilidade social mútua ou coletiva, isto é, requer que as partes envolvidas queiram que tal princípio normativo seja elevado ao status de lei ou que haja tal desejo pelo menos pela maioria da coletividade.

II Para uma abordagem mais aprofundada sobre a concepção de lei em H. Arendt, consultar Boff (20l0). 
Na segunda acepçáo exposta por Hannah Arendt, a concepção de lei é originária da tradição grega (nomos). Sob esse segundo prisma, a lei como nomos resulta da identidade entre lei e cidade (polis). Enquanto lex significa relaçáo e ligação, nomos carrega o sentido de demarcação, fronteira, proibição, fixação de limites. Por isso, é denominada "lei mural", ou seja, separava a vida privada do espaço público, isto é, da comunidade política dos cidadãos (BOFF, 2010). Essa visão de lei se explica pela estrutura política da época e pela autonomia e independência de cada cidade-estado, com suas leis próprias. Por esse motivo, a noção de nomos é associada a muro, fortaleza, proteção, delimitação do espaço político para a proteçáo da polis e de seus cidadáos.

No contexto atual, podemos aplicar o raciocínio de que, no primeiro caso mencionado (lex), existe uma funçáo educativa implícita na concepçáo de lei, que pressupóe uma cultura política democrática, fundamentada no diálogo cívico e no debate público, outro elemento relevante na discussão política sobre lei e educação. Na teoria política clássica, a interação é a base da ação política, ideia que sustentou o primeiro modelo de prática de cidadania e de democracia, como relata Hannah Arendt em $A$ condição humana (1983). Os debates públicos constituíram a atividade emblemática desse modelo de esfera, pois democratizaram as opiniōes e substituíram a transmissão autoritária de ideias, herança do pensamento mítico. Pelos debates públicos, a razão emancipou-se da mitologia e permitiu uma açáo política livre, racional e democrática. Dessa forma, o saber passa a ser visto como resultado da discussáo racional pública e náo mais dos oráculos realizados pelos sacerdotes a portas fechadas. Assim, a ágora transforma-se no coração da polis, para onde se dirigem os sábios, os poetas e os primeiros filósofos.

A história mostra que a política é construída a partir de interaçóes, ideia recorrente entre os expoentes das Ciências Sociais. Durkheim (2002), ao discorrer sobre as formas de Estado e a democracia, destaca o papel do Parlamento como mediador das relaçóes entre Estado e sociedade, ao mesmo tempo que salienta a interação entre os eleitores e seus representantes. Existem, portanto, diversos níveis, vetores e instâncias de interação política, e isso é apontado pelo autor como essencial para evitar a constituiçáo de um estado anômico. A interação política, portanto, é um dos fatores que contribuem para manter a coesáo social e evitar situaçóes de anomia, além de reforçar os vínculos morais entre os concidadáos, ideia desenvolvida nos estudos políticos brasileiros por Avritzer (2000), Sousa (1999, 2000), entre outros. 
De forma mais específica, Weber (1999) enfatiza o papel do Parlamento como órgão de mediaçáo entre a sociedade e o Estado e, portanto, como agente moral da política e responsável pelo equilíbrio de forças ideológicas, a fim de assegurar um campo de alianças que favoreça o poder legal e as formas legítimas de dominação política, por meio da racionalização das leis. $\mathrm{O}$ principal obstáculo para o Parlamento cumprir essa missáo, segundo a leitura weberiana, é o que ele denomina de política negativa, ou seja, uma agenda focada nos trâmites internos do processo legislativo, sem interesse para os eleitores e a sociedade, como, por exemplo, a apreciaçáo de requerimentos, oitiva de autoridades, ${ }^{12}$ reunióes e eventos protocolares, discussáo de projetos sobre datas comemorativas, apresentaçáo de emendas, sessóes de homenagens e a obstruçáo da oposiçáo ao voto de determinados projetos de interesse da base aliada ao governo. Isso explica, por exemplo, por que uma lei, para estabelecer as diretrizes e bases da educaçáo nacional, ou para definir as metas educacionais para o período de uma década, permanece durante anos em discussáo no Congresso Nacional. Na realidade, a maior parte do tempo desse debate é desperdiçada sob a lógica dessa política negativa, na terminologia usada na sociologia política weberiana.

Uma das alternativas apontadas por Weber para a superação dessa característica endógena do Parlamento é a atuação de líderes partidários carismáticos, movidos pela ética da responsabilidade, que saibam contornar esses obstáculos e construir vínculos de confiança com a sociedade e os eleitores, criando, assim, predisposição para que haja um debate político favorável e positivo. Afinal, "a essência de toda política [...] é a conquista de aliados e de um séquito voluntário" (WEBER, 1999, p. 562). Outra característica do Parlamento, segundo a análise weberiana, é a dualidade entre palco e bastidores. Apesar da relevância do palanque, espaço privilegiado para a visibilidade dos discursos parlamentares sobre os projetos em discussão, os quais devem resultar em algum tipo de resposta dos eleitores, Weber chama a atençáo para a importância dos bastidores como espaço indispensável para a ação política e parlamentar. Segundo o autor, também pode haver interação política nos bastidores, especialmente com os líderes de opiniāo, que têm maior disposição para

12 Trata-se de reuniões destinadas a ouvir as autoridades, nas quais os parlamentares pedem esclarecimentos e informações sobre assuntos de responsabilidade da autoridade convidada. 
acompanhar as audiências públicas e os debates promovidos pelas comissóes, além das conversas reservadas. "Este trabalho realiza-se atrás dos bastidores, nas sessóes das comissóes e fraçóes e, entre os membros intensamente ativos, principalmente em seus escritórios." (WEBER, 1999, p. 562).

No caso das leis que regem a educaçáo e os planos que estabelecem as metas nacionais para o setor, a publicidade se dá em torno do que é discutido publicamente, mas, na realidade, as decisóes mais relevantes sáo tomadas nos bastidores, longe da visibilidade pública. A divulgaçáo é realizada a partir dos consensos e acordos tecidos no âmbito do sigilo das negociaçóes políticas. Para a população, o que conta é a versáo divulgada sobre as discussóes. Como, então, os debates legislativos sobre a legislação educacional podem ser atraentes para a população? Será que o cidadão se interessa pela dimensão processual da dinâmica legislativa e parlamentar ou o foco do interesse está mais relacionado com a esfera pragmática, ou seja, com o resultado e as consequências do que foi aprovado ou decidido? Como despertar a atençáo e o interesse pelo menos daqueles segmentos diretamente envolvidos no debate político sobre educaçáo, como professores, estudantes, pais e a comunidade escolar em sua dimensão mais ampla? Se a participaçáo pressupóe confiança do cidadáo, como superar a falta de confiança? Como motivar a participaçáo numa sociedade reconhecidamente desinteressada quando se trata de política, como é o caso da sociedade brasileira?

O interesse do cidadáo requer educaçáo política, ou seja, possuir valores republicanos e democráticos, informaçáo e conhecimento sobre a estrutura e as funçóes do Poder Legislativo, além de noçóes básicas sobre processo legislativo. A divulgação do debate parlamentar sobre educação pode ser considerada uma alternativa educativa, sob o prisma político? Tal iniciativa pode ter consequências políticas efetivas, do ponto de vista do aumento na confiança e do interesse do cidadáo? Nesse sentido, cabe lembrar que a divulgaçáo em si náo pode produzir tal eficácia. Afinal, como argumenta Luís Felipe Miguel, o ceticismo em relaçáo ao funcionamento das instituiçóes da democracia eleitoral é fruto de uma avaliaçáo realista de seu funcionamento, "já que, por diversos motivos e a despeito do tributo ritual à vontade soberana do povo, elas se mostram bastante impermeáveis à influência das pessoas comuns" (MIGUEL, 2008, p. 251). Em outra perspectiva argumentativa, Santos (2002a, 2002b) ressalva que a falta de participaçáo também pode ser interpretada como indício 
de confiança irrestrita do cidadão, com base no argumento de que, se o cidadão se abstém de participar, é porque confia nas instituiçóes políticas e em sua lógica de sistemas peritos, isto é, em sua expertise política. O fato é que tanto a educaçáo como a legislaçáo devem ser analisadas à luz do desenvolvimento do processo de racionalização cultural e política, como será explicado a seguir.

\section{Educação e legislação: racionalidade cultural e política}

A educação no sentido social e político mais abrangente, assim como a legislaçáo, encontram respaldo na análise weberiana sobre o processo de racionalização cultural do Ocidente, à luz do qual a legislação também deve ser compreendida como consequência das formas de dominação legítima (WEBER, 1999). Em outras palavras, na abordagem weberiana, educação e lei são vistas como resultantes do projeto amplo de racionalizaçáo das sociedades ocidentais, contribuindo ambas para a secularização e o "desencantamento" do mundo social.

Racionalização para Weber é um conceito supranacional, no sentido de tipo ideal (SOUSA, 1999). Apesar de não ter apresentado uma definição fechada, Weber utiliza o termo em vários de seus escritos, especialmente em Economia e sociedade (1999), com o propósito de caracterizar o processo que impulsionou o desenvolvimento ocidental e uma das formas específicas de dominação legítima, com respaldo legal, ou seja, das leis. Portanto, trata-se de um conceito considerado central para a compreensáo de seu pensamento, além de um instrumento essencial "para se entender o desenvolvimento social, o progresso técnico das sociedades, bem como o projeto de modernidade no qual nos inserimos" (CARDOSO, 2008, p. 257). A importância do conceito reflete-se nas formulaçóes de Weber sobre o potencial civilizador da racionalizaçáo, seja na economia, na ciência, na educaçáo, na cultura, na política e na legislação. Em sua dimensão intelectual, diretamente associada à educação, a racionalizaçáo é vista por Weber como indutora do processo civilizatório.

As reflexóes cobertas pelo escopo da sociologia política weberiana sobre racionalizaçáo se complementam com a sua tese da secularizaçáo e do desencantamento do mundo, formando uma tríade conceitual exemplar (racionalizaçáo, secularizaçáo, desencantamento) que resulta do afastamento do mundo social do universo das crenças religiosas, ou seja, do mundo encantado pelas explicaçóes mágicas sobre a natureza e as relaçóes humanas e sociais 
(PIERUCCI, 2000). À medida que avançam os processos de racionalizaçáo social por meio da ciência, da técnica, da educação e das normas legais, as sociedades ocidentais se afastam do mundo das explicaçóes sobrenaturais e das relaçóes baseadas em narrativas mitológicas. Assim, o mundo desencantado é aquele que "prescinde das escolhas e da intervenção criadora da agência social, motivada por impulsos exógenos àqueles contidos e gerados no e pelo mecanismo burocrático-administrativo que, tecnicamente, perpetua a ordem sociopolítica" (SOARES, 2000, p. 343). Portanto, a educaçáo e as leis despontam como elementos racionais, livres do jugo do pensamento mágico e das explicaçóes sobrenaturais acerca da vida, da natureza e das relaçóes sociais.

A tríade conceitual mencionada é consequência do papel que a educação passou a exercer como formadora de valores e modeladora de comportamentos sociais, suplantando a religiâo. Se antes as igrejas é que formavam as consciências, com o processo de secularização, as escolas é que passaram a atuar na orientaçáo de valores, na formação da personalidade e na "desmagificação" do mundo. ${ }^{13}$ Os sistemas educacionais foram fundamentais na construçáo do projeto de modernidade cultural e essa "modernidade desencantada" é fundada no princípio da subjetividade, pois "a transiçáo para a modernidade é um processo de internalização e de subjetivação, no qual o caminho para dentro tanto mais demora, quanto mais leva para nós mesmos - e náo mais para cima, para Deus" (SCHLUTCHER, 2000a, p. 18). Afinal, ao contrário da religiáo, o pensamento racional náo responde de forma objetiva e imperativa ao que devemos fazer e como devemos viver. É pela educação que o sujeito moderno adquire as ferramentas intelectuais e cognitivas para sua açáo no mundo. Ao lado da educaçáo, as leis atuam como elementos para garantir a estabilidade das relaçóes sociais, sem a intervençáo de regras religiosas ou de outra ordem que náo seja o pensamento racional e objetivo.

Assim, tanto a educação quanto a legislação, na concepção de Weber, representam a dimensáo cultural do processo de racionalização ocidental. Uma vez que "os fenômenos intelectuais mais significativos da história moderna foram a desilusão, a intelectualização e a racionalização do mundo, a ciência e a educação afetam diretamente o significado do mundo moderno"

13 O desencantamento do mundo ou "desmagificação", na perspectiva weberiana, implica a substituição das visões mágicas e religiosas pelas explicações racionais, filosóficas e cientificas. 
(SCHLUTCHER, 2000b, p. 60). Isso porque o conhecimento científico, ao espalhar a crença de que em princípio é possível dominar todas as coisas por meio do cálculo, quebrou o monopólio explicativo das religióes de redenção. Até então, tais religióes detinham o poder de atribuir explicaçóes sociais a partir do regime de crenças que propagavam. Essa reflexáo reforça a tese de que o discurso de Weber sobre o papel da ciência e sua relação com a política ${ }^{14}$ deixa implícito que se "trata também de um discurso sobre a educaçáo política”, uma vez que Weber defendia a autonomia das universidades para que "elas não se tornassem igrejas, nem seitas, nem instituiçóes de apoio direto ao Estado" (SCHLUTCHER, 2000b, p. 80). Esse processo possibilitou que a educação se tornasse protagonista de narrativas sociais desvinculadas do pensamento mágico, o que nos levou à elaboraçáo de uma prosa do mundo ${ }^{15}$ renovada e ancorada em bases racionais e legais. Cabe reforçar que o próprio conceito de progresso, intrinsecamente associado à modernidade, decorre da noçáo de desencantamento do mundo e sua consequente secularizaçáo e normatizaçáo legal e racional, como já foi explicado. Percebemos ainda que a educação política constitui o solo epistemológico das ideias de Weber quando ele afirma que "somos seres culturais, dotados da capacidade e da vontade de tomar atitudes ponderadas com relação ao mundo e dar-lhe significado", como observa Schlutcher (2000b, p. 63). Essa visão de educação está diretamente relacionada à ideia weberiana de dominaçáo legal, ou seja, formas de poder baseadas em estruturas e leis racionais e impessoais, orientadas para o bem coletivo, pela ética da responsabilidade e não mais pela ética da convicção, típica do âmbito religioso. ${ }^{16}$

Para Weber, a moralidade ocidental na perspectiva de necessidade de compreensáo do mundo nasceu como movimentos endógenos à racionalização religiosa. Assim, tanto a educação como a legislação são vistas como instrumentos de libertação do homem moderno em relação ao "jardim mágico

14 Trata-se, aqui, das duas célebres conferências de Weber, proferidas na Universidade de Heidelberg, nos anos de 1918 e 1919, com o título de "A ciência como vocação" e "A política como vocação", respectivamente.

15 Expressão utilizada por Michel Foucault em As palavras e as coisas para designar a construção de narrativas e epistémes sobre a vida social e a cultura.

16 De forma muito resumida, a diferença é que a ética da responsabilidade, como expressão racional, considera o cálculo estratégico das ações e leva o seu agente a arcar legalmente com as consequências de seus atos, enquanto a ética da conviç̧ão é baseada puramente em elementos subjetivos e emocionais, como a fé religiosa e o pensamento político, ideológico e dogmático. 
das teodiceias religiosas" que moldavam eticamente o mundo e definiam as regras e normas para a condução da vida coletiva. Na modernidade, a escola e a lei é que exercem tal função. Nessa perspectiva, a educaçáo e a legislação são fundamentais como categorias heurísticas, pois ambas são abraçadas pela concepçáo de Weber, mas livres da epistemologia iluminista dual que opunha ciência e religiáo, o que, no contexto atual, podemos entender como conhecimento científico e saberes tradicionais (normas baseadas nos costumes e mitos). Trata-se de uma concepçáo plural que engloba a lógica de pensamento complexo, segundo a abordagem de Edgar Morin (1994), amplamente utilizada nos estudos sobre educaçáo, no contexto contemporâneo. Educação e legislação devem, portanto, ser compreendidas como um fenômeno político e cultural com múltiplas interfaces, mas organizadas segundo a lógica da epistemologia da complexidade, um dos paradigmas que orientam a discussáo teórica sobre os sistemas e práticas educativas do contexto contemporâneo (MORIN, 2002).

A essência do pensamento complexo, segundo Morin, é o desenvolvimento de habilidades para se aprender a pensar transversalmente as questóes de interesse social e de relevância política e cultural no mundo contemporâneo, o que requer policompetências cognitivas. Trata-se, pois, de um campo hermenêutico aberto, com uma lógica integradora, capaz de produzir uma síntese pluridisciplinar de ideias e saberes. A complexidade inclui o estudo da racionalidade (logos), das formas de poder (kratos) e das condutas sociais (ethos). Em síntese, constitui um campo dialético e dialógico por essência, que se reflete diretamente no contexto da educaçáo como diálogo complexo e transversal de saberes que produz encontro de identidades e espaços críticos para a discussão sobre o papel das leis em um sistema democrático. Entendendo que a educação deriva da inserção em relaçóes sociais multifuncionais (PETITAT, 2011) é que se justifica tal enfoque, assentado na hipótese de que o desenvolvimento de campos integrados de saberes implica sua inserçáo no âmbito dessas relaçóes, abrangidas pelo conceito de educaçáo difusa, ou seja, práticas educativas em sua dimensão mais ampla (além do contexto escolar) que envolvem atividades sociais, culturais e políticas "orientadas à transmissáo de comportamentos, disposiçóes, crenças e competências" (PETITAT, 2011, p. 366). Isso pressupóe uma concepçáo de educaçáo integrada às relaçóes e atividades do cotidiano, isto é, às relações educativas náo especializadas e náo regulamentadas, inseridas nas novas dinâmicas de socialização e aprendizagem 
da chamada "modernidade líquida" (BAUMAN, 2001), resultante dos desdobramentos, continuidades e redefiniçóes do processo de racionalizaçáo analisado por Weber. A epistemologia da complexidade, portanto, deve ser compreendida como consequência da racionalizaçáo, âmbito que inclui a legislaçáo e a educação, como já foi explicitado anteriormente.

\section{Análise dos dados}

A descrição e a análise dos dados têm início com o perfil dos cidadãos que responderam ao questionário. $\mathrm{Na}$ sequência, apresentamos os dados, de acordo com a ordem das perguntas. Como se trata de uma sondagem sobre educaçáo, supomos que a variável escolaridade seja relevante para a análise e compreensão dos resultados. Por essa razão, optamos pela apresentação dos dados gerais em comparação com as respostas vinculadas ao grau de instruçáo dos respondentes, a fim de avaliar se existem diferenças e/ou semelhanças entre os três níveis do perfil dos respondentes, no que se refere a tal variável.

\section{I Perfil dos respondentes}

Antes da descriçáo dos dados, apresentamos um perfil dos cidadáos que responderam ao questionário (Gráficos 1 a 3), com base nas seguintes variáveis: escolaridade, faixa etária, gênero, regiáo geográfica e ocupação/profissáo. Prevalecem os percentuais referentes à escolarização superior $(45,35 \%)$, gênero masculino $(62,38 \%)$, na faixa etária acima de cinquenta anos $(45,45 \%)$.

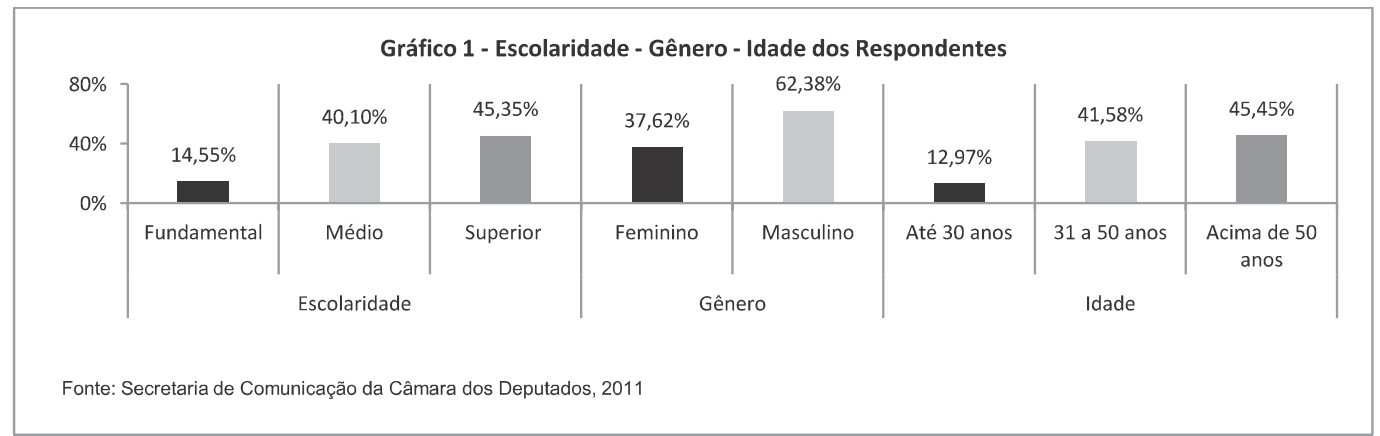

Quanto à regiáo dos respondentes, prevalecem as regióes Nordeste $(32,08 \%)$ e Sudeste $(29,7 \%)$, com menor expressividade da regiáo Norte $(6,34 \%)$, como podemos observar no gráfico 2 . 


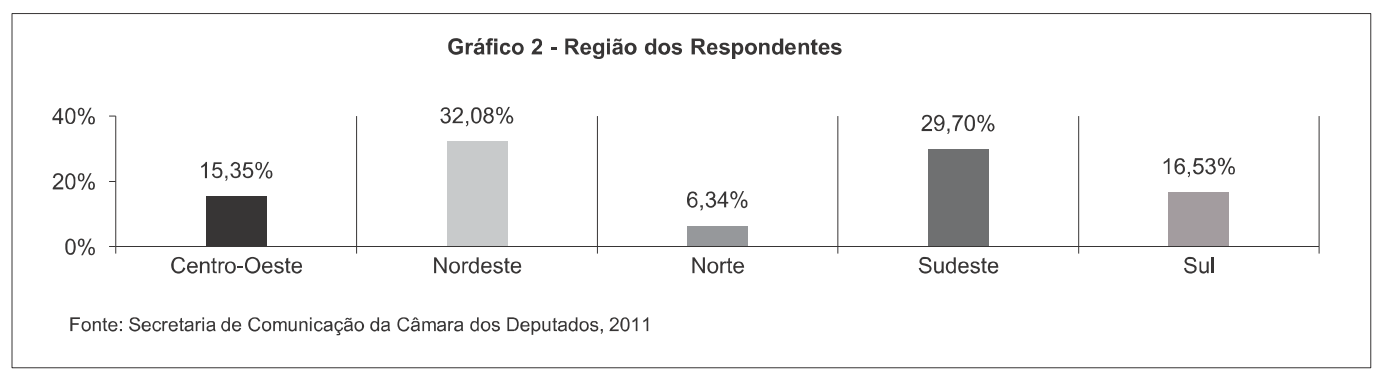

$\mathrm{Na}$ área profissional, destacam-se autônomos e campos afins à educaçáo, como mostra o gráfico 3. O predomínio de "outros" se justifica pela amplitude do cadastro nacional de ocupaçóes.

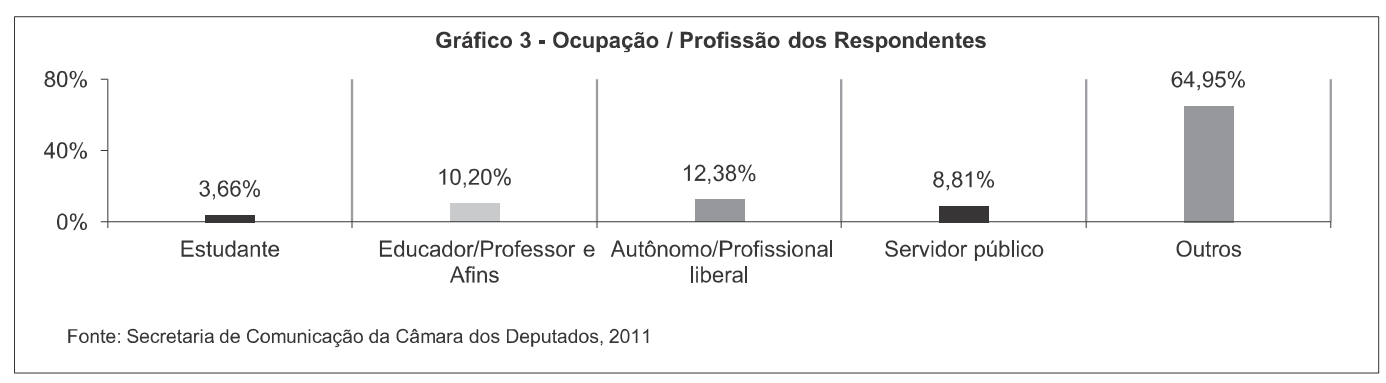

Cabe mencionar o próprio sistema de classificação das profissóes usado, ${ }^{17}$ uma vez que a categoria "outros" atinge 64,95\%, ou seja, quase dois terços. O predomínio de "outros" passa a ser um dado relevante na medida em que é indicado como a maioria dos entrevistados, portanto. Resulta do somatório de profissóes fragmentadas e dispersas, tendo em vista que o cadastro nacional de ocupaçóes registra 7.258 títulos ocupacionais. A amplitude desse universo dificulta a citação nominal de categorias profissionais que representam esse percentual.

\subsection{Nível de conhecimento e contribuições da LDB}

O nível de conhecimento específico dos respondentes sobre a LDB é muito baixo. Como mostram os gráficos 4 e 5, 64,55\% declararam náo conhecer o conteúdo da lei.

17 O sistema é baseado na Classificação Brasileira de Ocupações (CBO), instituida pela Portaria Ministerial $n^{\circ}$ 397/2002. A CBO contempla 7.258 títulos ocupacionais. A finalidade é a identificação das ocupações no mercado de trabalho para fins de registros administrativos. Mais informações em <http://www.mtecbo.gov. br/cbosite/pages/saibaMais.jsf> 


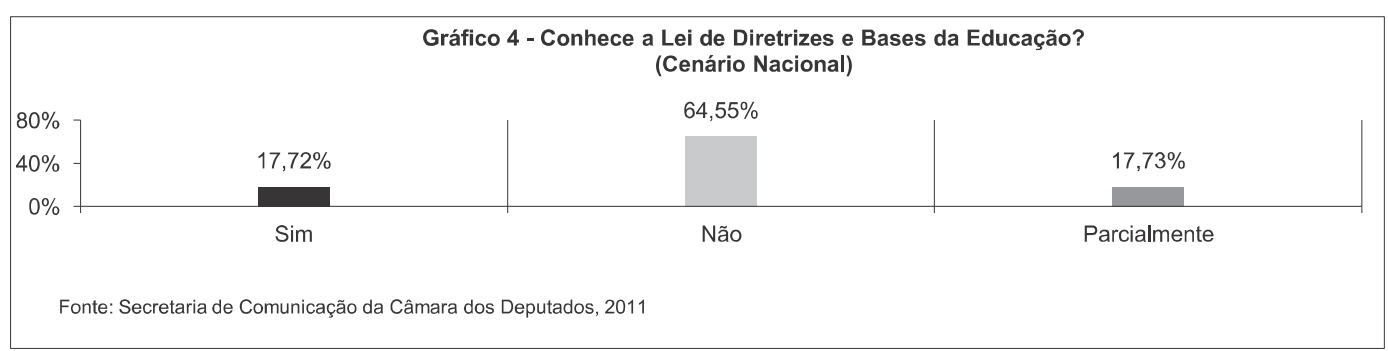

O grau de escolaridade interfere diretamente no nível de informação e conhecimento do cidadão sobre a LDB, conforme o gráfico 5 . Enquanto no cenário geral o percentual de pessoas que não conhece a lei varia de 53,1\% a $72,35 \%$, a situação é diferente quando se considera especificamente o segmento com nível superior, no qual a média dos que afirmam conhecer a lei atinge 48,04\%, resultado do somatório das alternativas "Sim" (29,03\%) e "Parcialmente" (19,00\%).

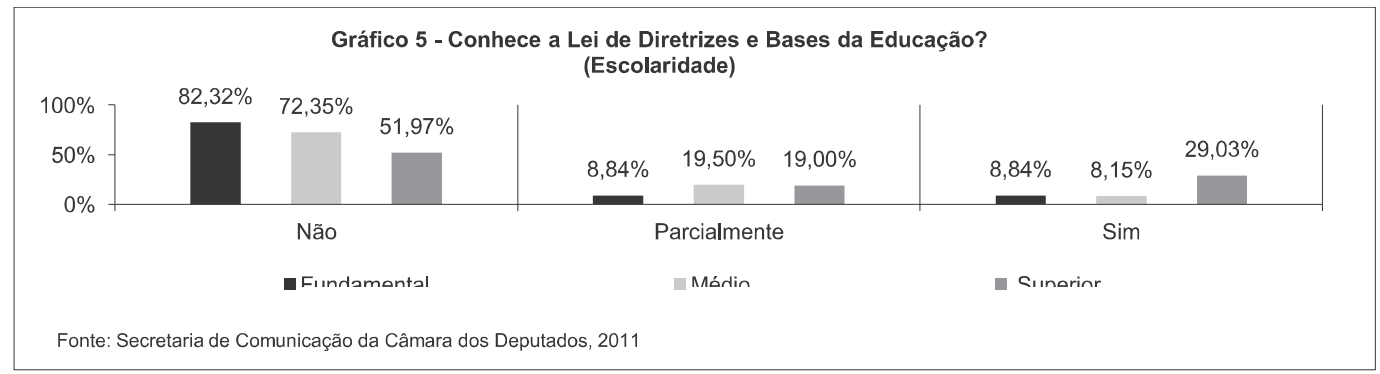

Aqueles que responderam afirmativamente (17,72\%) apontam as seguintes contribuiçóes mais relevantes da legislaçáo nos últimos 15 anos: (a) definiçáo de políticas públicas para promover a universalizaçáo do ensino $(21,10 \%)$; (b) fortalecimento do conceito de educação compartilhada pela escola, pela família e pelo ambiente de trabalho (19,85\%); e (c) definição das responsabilidades dos poderes públicos, da família e da comunidade escolar $(19,35 \%)$, como podemos ler no gráfico 6 . 


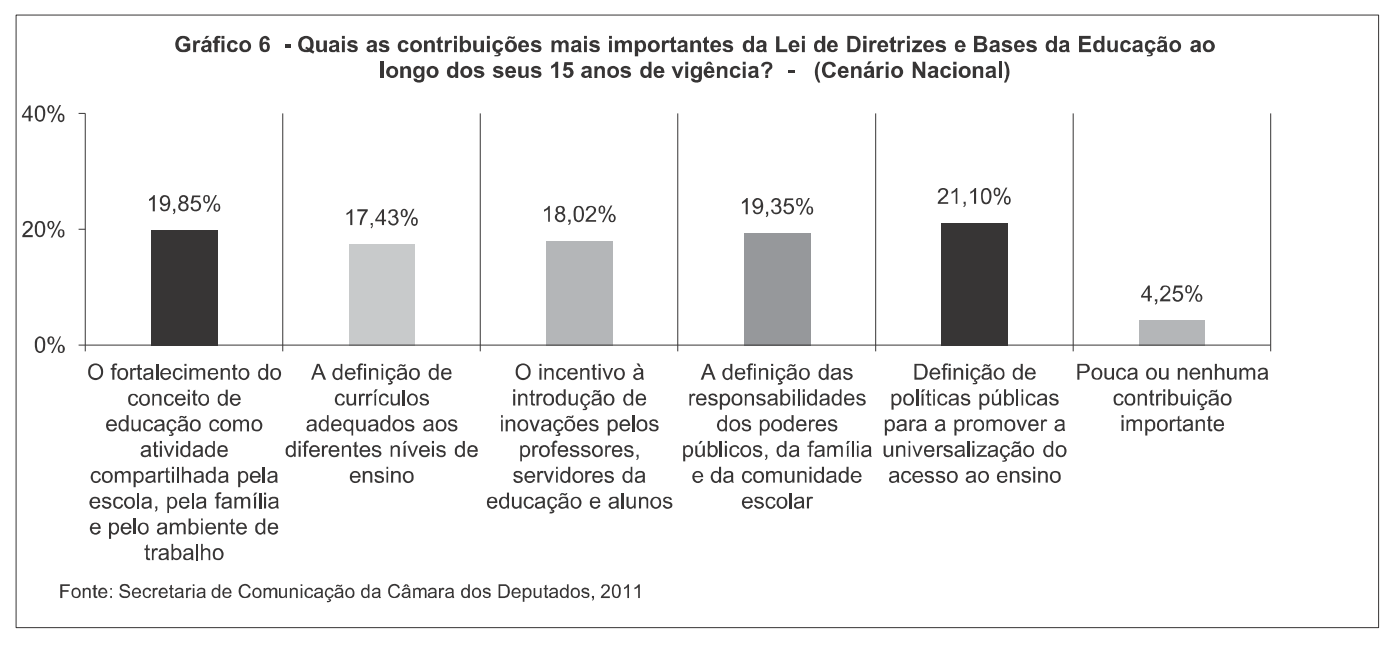

Na comparação com o nível de escolaridade, como mostra o gráfico 7 , quando se trata de apontar as principais contribuiçóes da referida legislação, a fragmentaçáo e dispersáo das respostas coincide com o percentual referente aos dados gerais. Destaca-se a visáo compartilhada dos respondentes em relaçáo à definiçáo das responsabilidades dos poderes públicos, da família e da comunidade escolar. O reconhecimento das responsabilidades e atribuiçóes dos principais atores pode ser considerado um dos legados da LDB. Chama a atençáo ainda a percepção dos respondentes em relação à definição de conteúdos curriculares. A formulação de políticas públicas para promover a universalizaçáo do acesso ao ensino público também é outro legado da LDB na percepção dos cidadáos consultados. No campo das disparidades, o gráfico 7 registra $11,89 \%$ de cidadáos com ensino fundamental que identificam pouca ou nenhuma contribuiçáo relevante da LDB ao longo de seus 15 anos de vigência. 


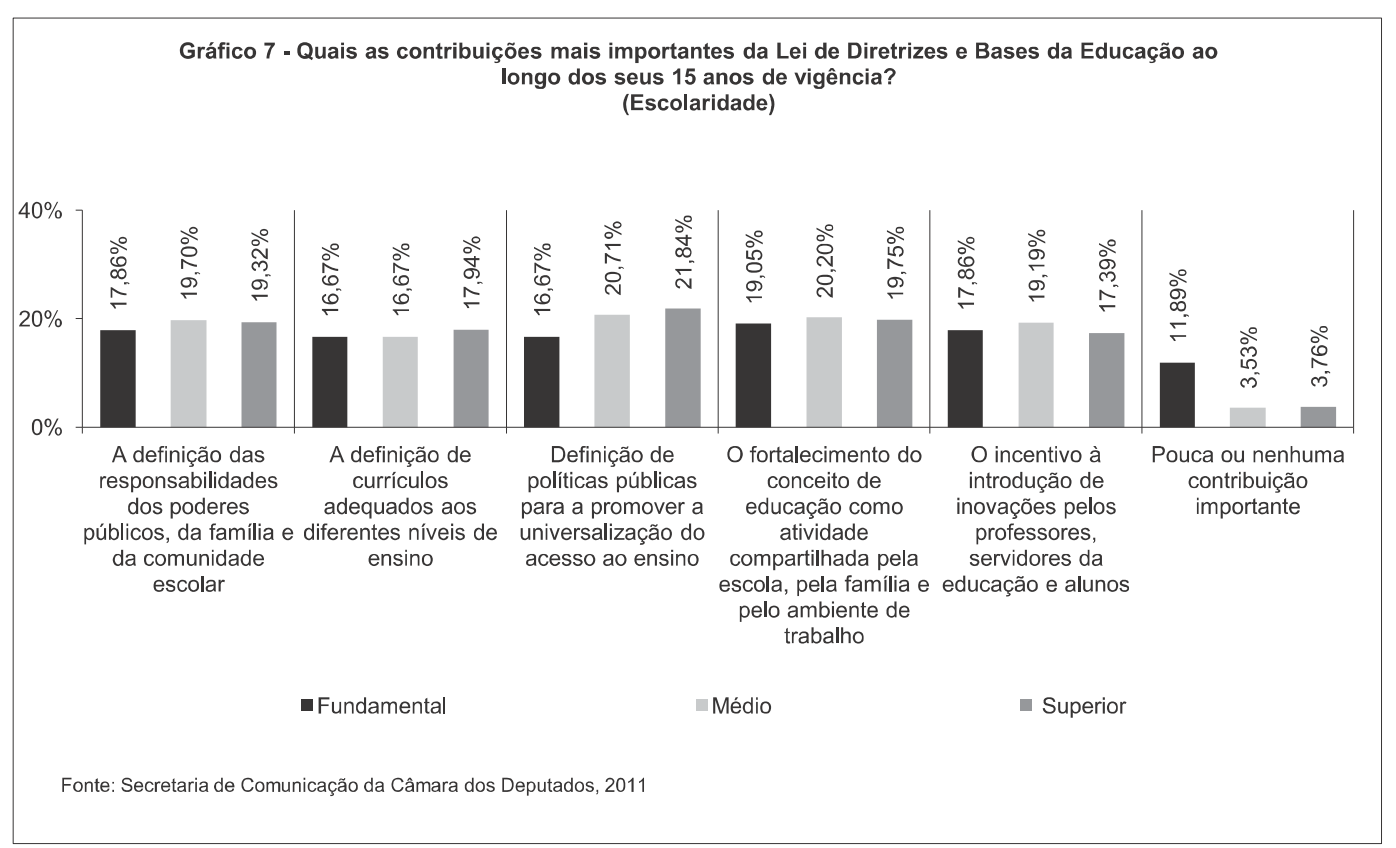

Em geral, o balanço é equilibrado e positivo entre os diferentes níveis de instrução. $\mathrm{O}$ aprofundamento analítico dessa questáo exigiria estudos qualitativos para ampliar as possibilidades de exame do campo de relaçóes entre educação formal e vida cotidiana, esfera pública e mundo da vida, razão, cultura e ideologia, conforme indicam os autores citados no referencial teórico, especialmente Weber, Arendt e Habermas.

\subsection{Nível de conhecimento do PNE}

Como mostram os gráficos 8 e 9 , cerca de $72,08 \%$ dos respondentes afirmam não acompanhar o debate político sobre o $\mathrm{PNE}$, cuja tramitação na Câmara dos Deputados teve início em dezembro de 2010, o que também pode ser considerado um indício de que esse mesmo percentual pode ser atribuído a quem náo conhece o conteúdo e as propostas do PNE.

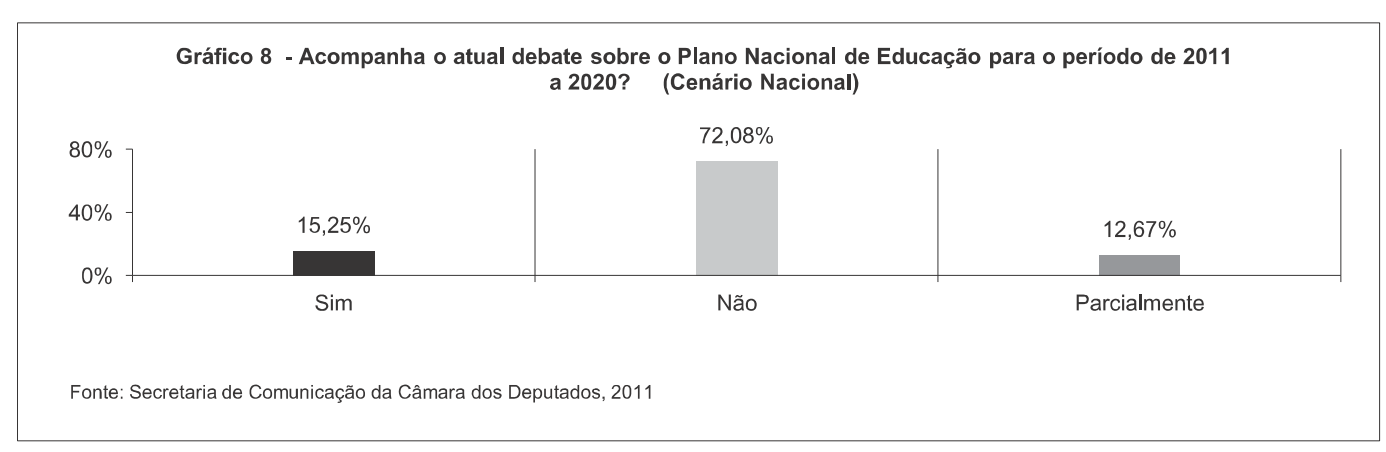


Ao se considerar o grau de escolaridade, percebemos que náo há variaçáo expressiva, com os percentuais similares ao cômputo geral das respostas, como podemos observar no gráfico 9 .

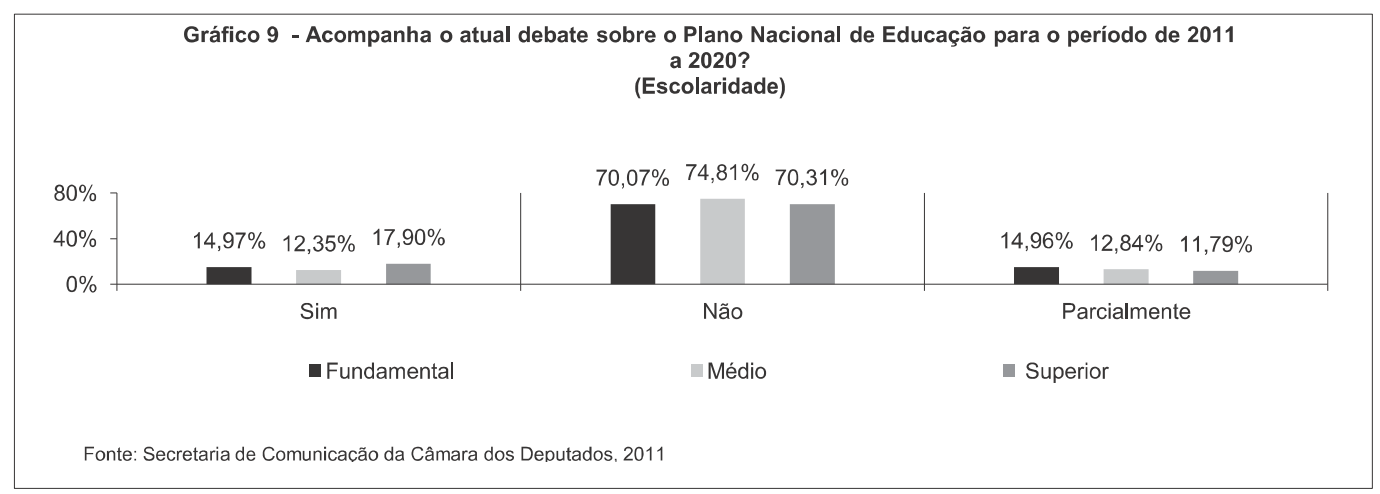

Para os que afirmam acompanhar a discussáo, predomina a expectativa genérica de melhoria da qualidade da educação $(21,38 \%)$, seguida da melhoria do ensino técnico-profissionalizante $(20,04 \%)$, erradicação do analfabetismo $(19,63 \%)$ e promoçáo da educaçáo para a diversidade e o respeito às diferenças (18,29\%), como registra o gráfico 10 .

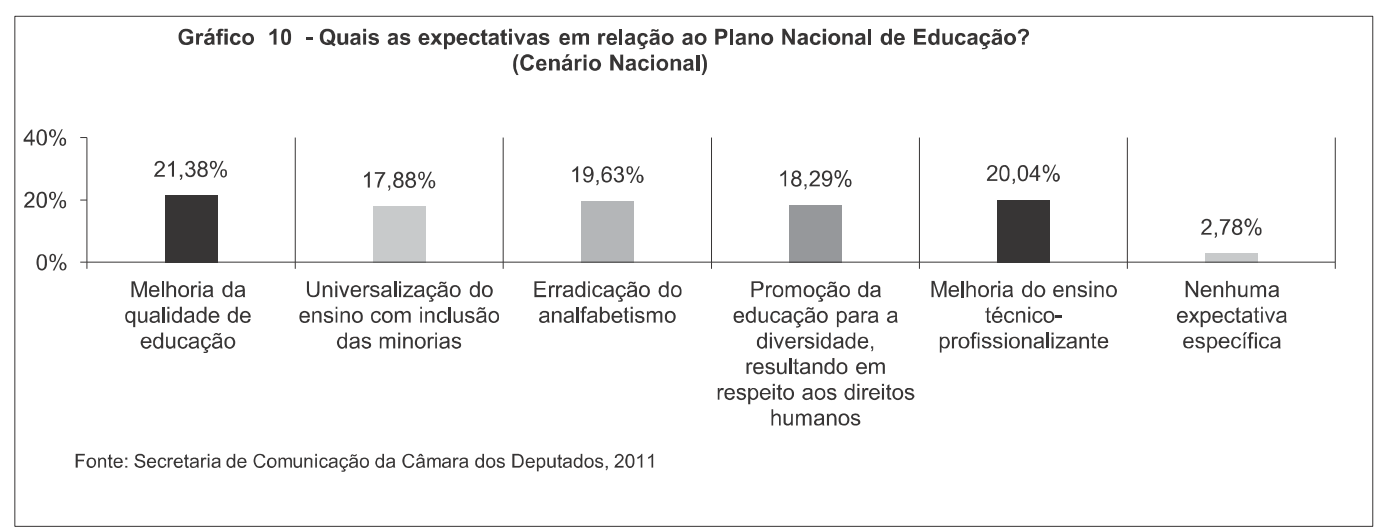

Tendência similar ao registrado anteriormente (Gráfico 9) repete-se em relaçáo às expectativas quanto ao PNE, ou seja, há uma diferença pouco significativa entre os níveis de escolaridade, como vemos no gráfico 11 . 


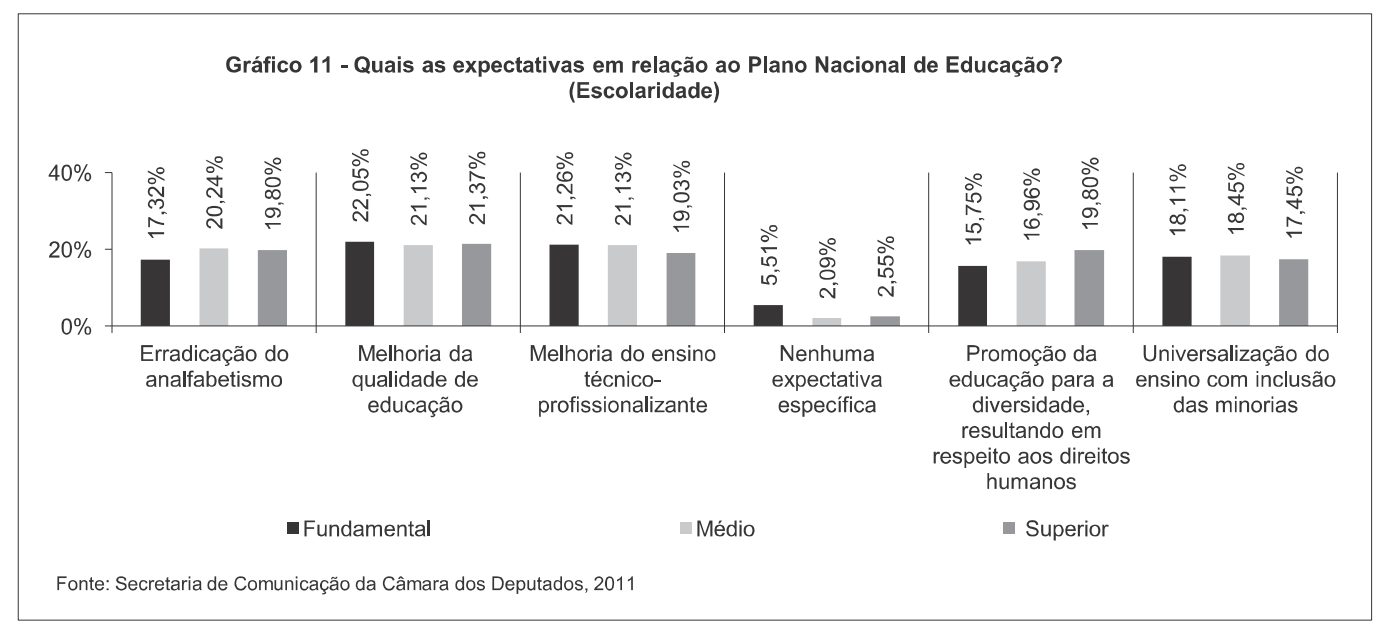

\subsection{Percepção dos cidadãos sobre avanços na educação}

Indagados sobre se reconhecem algum avanço na educaçáo pública nos últimos anos, 42,08\% dos cidadáos optaram pelo "Sim" e 20,30\% responderam "Em parte". Somados os dois itens dos que reconhecem avanços (total e parcialmente), chega-se ao total de 63,38\%, o que representa elevada percepção social sobre melhorias no ensino público brasileiro nas últimas décadas, especialmente após o início da vigência da LDB, em 1996 (Gráfico 12).

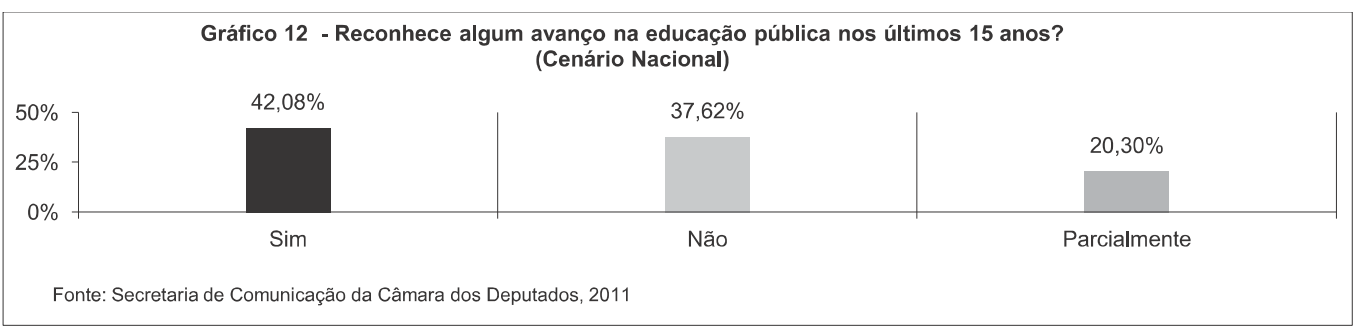

$\mathrm{Na}$ comparaçáo com os segmentos de escolaridade superior, observamos que a opiniáo muda quando se trata do tópico que avalia se os cidadáos reconhecem avanços no campo educacional durante o período dos 15 anos de vigência da LDB.

Como mostra o gráfico 13 , quanto maior a escolaridade, maior o percentual de respostas afirmativas (considerando-se o somatório do "Sim" e do "Parcialmente", visto que este último também é uma resposta afirmativa). Contudo, o gráfico 15 reforça a consonância com o cenário geral de opiniáo. 


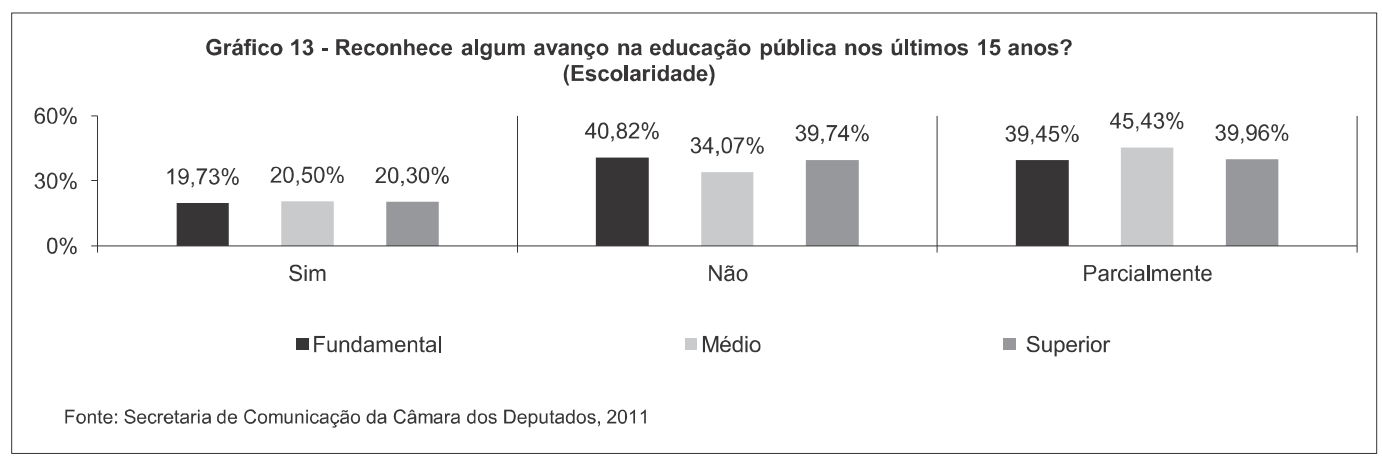

Entre os avanços mais destacados pela populaçáo consultada estáo: (a) ampliaçấo das redes de escolas técnicas e tecnológicas (14,48\%); (b) criação dos sistemas de avaliaçáo do ensino, como o Processo Seletivo de Avaliaçáo Seriada (PAS) e o Enem (14,40\%); e (c) implantação de universidades no interior do país $(13,87 \%)$. O detalhamento estatístico consta nos gráficos 14 e 15 .
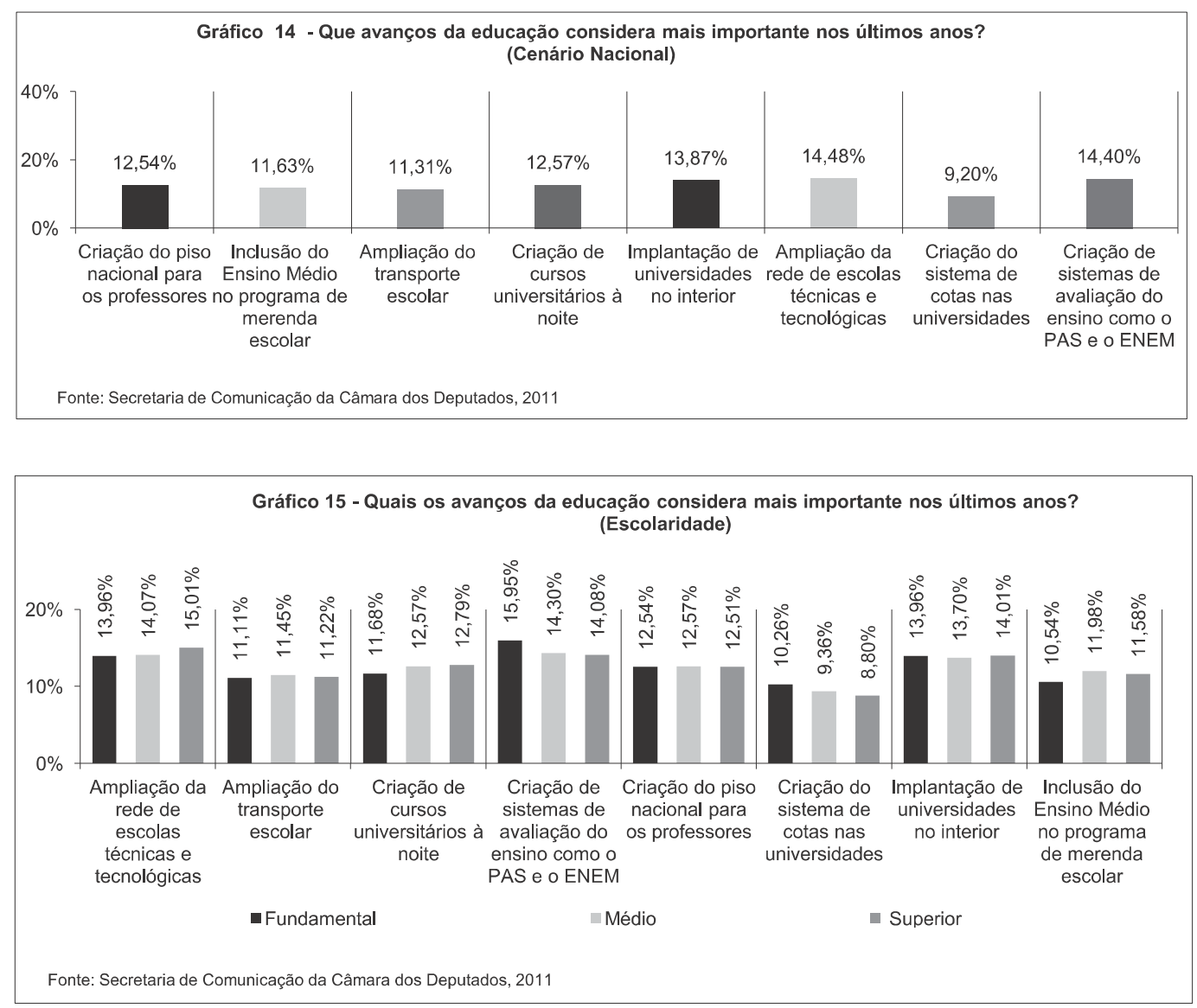
Percebemos pouca variaçáo da percepção sobre os avanços da educaçáo nos últimos anos entre respondentes de diferentes escolaridades. Destaca-se, entre as maiores variaçóes, a indicação da (a) criação de sistemas de avaliação de ensino, como PAS e Enem, com 16\% de respostas entre o público de nível fundamental e $14 \%$ para os níveis médio e superior de ensino. A questáo que teve menor porcentagem de respostas como principal avanço da educaçáo foi a (b) criaçáo do sistema de cotas nas universidades, que apresentou uma leve diminuiçáo da menor para a maior escolaridade, $10 \%$ de respostas entre o nível fundamental e $9 \%$ para os níveis médio e superior.

\subsection{Como o Poder Legislativo pode contribuir para melhorar o ensino público?}

Como se trata de uma pesquisa de opiniáo focada na relação entre legislaçáo e educaçáo, o questionário apresentava um item sobre a opiniáo da populaçáo quanto à atuaçáo do Poder Legislativo no sentido de aperfeiçoar o ensino público. Os dois itens associados à gestão e fiscalização dos recursos públicos destinados à educaçáo são apontados como os mais relevantes quando se trata do papel do Poder Legislativo em relação à instruçáo pública. Como mostra o gráfico 16 , fiscalizar a aplicação dos recursos $(28,88 \%)$ e assegurar mais recursos orçamentários $(25,40 \%)$ são os itens principais, o que soma 54,28\%. Em seguida, destacam-se as seguintes açóes legislativas: aprovaçáo de medidas para promover a capacitaçáo dos professores $(25,70 \%)$ e promoção de debates sobre temas educacionais (20,02\%). Portanto, o Poder Legislativo é visto pelos cidadáos consultados mais como um órgáo capaz de interferir na gestão da educação, em detrimento da funçáo de discutir e promover debates.

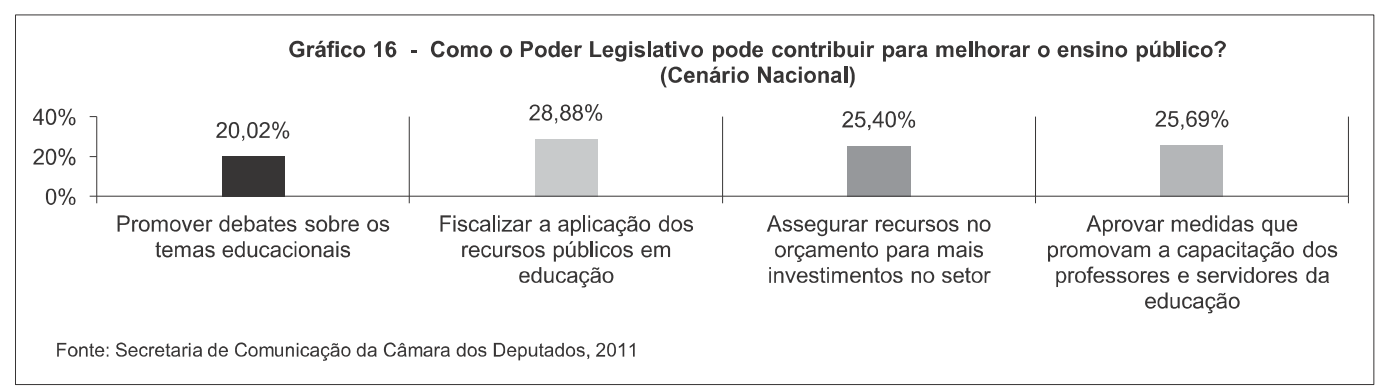

O diferencial nesse quesito, no que se refere especificamente aos dados segmentados por escolaridade dos respondentes, diz respeito ao percentual 
um pouco mais elevado de cidadáos com ensino médio que reconhecem a função de promover debates sobre temas educacionais como uma contribuiçáo relevante do Poder Legislativo para a melhoria da qualidade do ensino público, como mostra o gráfico 17.

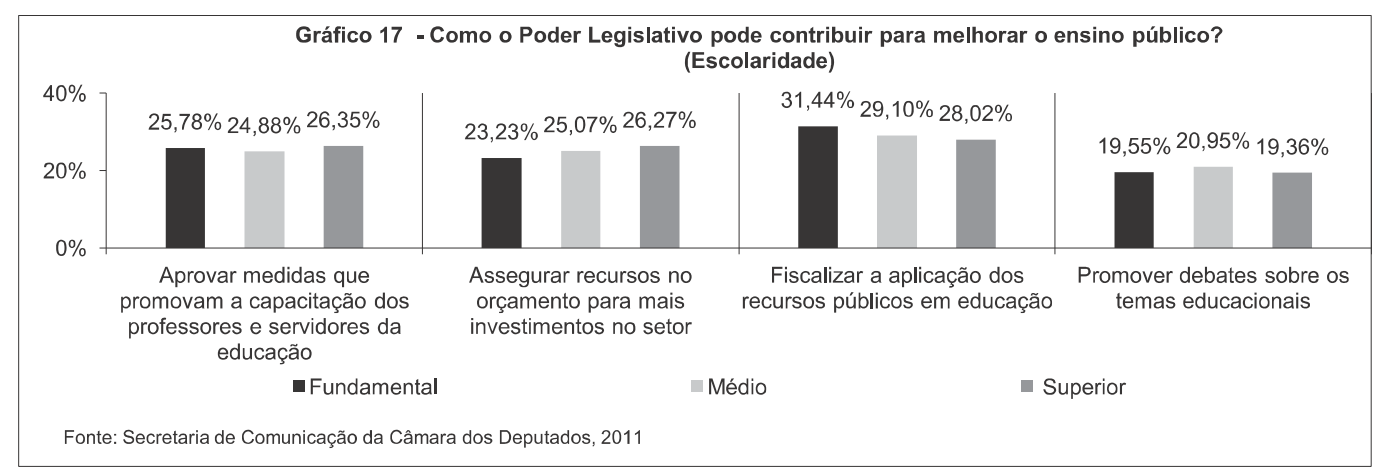

\section{Conclusões}

Após a análise dos dados, o que observamos é que, de fato, o grau de escolaridade é um fator interveniente na percepção dos cidadáos sobre os principais aspectos da educaçáo contemplados pela sondagem. Chamam a atençáo especialmente as concepçóes dos respondentes com nível superior, sobretudo no que se refere à importância da pesquisa científica, à atualizaçáo dos conteúdos dos currículos escolares e à melhoria das bibliotecas, por exemplo. A distinçáo do ponto de vista do nível de escolarizaçáo corrobora os pressupostos gerais do referencial sociológico utilizado no estudo, especialmente no que se refere ao princípio weberiano da racionalizaçáo. Quanto maior o grau de instruçáo do cidadáo consultado na pesquisa, maior sua capacidade de formular argumentos racionais e de opinar sobre as questóes postas pela sondagem de opiniáo.

A baixa escolaridade, portanto, parece um fator relevante que faz com que a educaçáo náo seja reconhecida pela maioria da populaçáo consultada como um tema político, no sentido amplo do termo. Apesar de ser apontada consensualmente como uma questáo de interesse nacional (como algo importante para todo o país e náo apenas para uma ou outra regiáo), é vista mais como um problema social e cultural, sem ênfase para a conotaçáo política, principalmente quando se trata do reconhecimento da esfera do Poder Legislativo como uma instância de debate público sobre políticas públicas educacionais. 
O papel do Poder Legislativo é associado pelos cidadáos consultados diretamente à garantia de recursos orçamentários e à fiscalização financeira relativa à aplicaçáo dos investimentos públicos no setor. Nesse sentido, reforça-se a imagem do Estado como provedor e garantidor de serviços e dos indivíduos como cidadãos-clientes. Essa situação de desconhecimento e mesmo desinteresse por essa temática táo importante para a sociedade brasileira leva-nos à conclusão de que não se percebe a educação como elemento de racionalização imprescindível a todos, mas sim como produto para usufruto individual. Isso fica evidente no grande número de respostas quanto à criaçáo do PAS e do Enem como um dos principais avanços da educação, pois basicamente esses sistemas funcionam para modificar a forma de acesso à universidade, ao maquiar o já desigual vestibular tradicional. Essa percepçáo individualista da educação dificulta a percepçáo da função política do Poder Legislativo para a melhoria da educação em todos os níveis, por meio do debate público e da produção legislativa. Dessa perspectiva, a legislaçáo sobre educaçáo não é percebida pelos cidadáos como um instrumento racional para promover a cidadania, a cultura pública e o fortalecimento da esfera pública, ao contrário do que defendem Weber, Arendt e Habermas.

Reflexo direto dessa concepção utilitária e de apropriação individualista da educação é o baixo nível de interesse pela legislação educacional e pelo debate político sobre o planejamento do Estado para o setor. No caso da LDB, $64,55 \%$ dos cidadáos consultados declararam náo conhecer o conteúdo da lei mais importante para o setor. Quanto ao PNE, cerca de 72,08\% dos respondentes afirmaram náo acompanhar o debate político sobre o plano, durante sua tramitação. Trata-se do principal instrumento do Estado brasileiro em termos de planejamento educacional, para todos os níveis, a vigorar durante o período de uma década. Se náo há interesse nem pela legislaçáo, nem pelo planejamento estatal, que ideia, afinal, a população brasileira tem de educação pública? Há que considerarmos, porém, que o desconhecimento ou o pouco interesse dos sujeitos consultados sobre a LDB e o PNE náo significam, necessariamente, que os cidadáos brasileiros náo se interessam pela educação pública. Certamente seria uma generalização temerária, se feita de forma categórica. $\mathrm{O}$ aprofundamento crítico de tal questáo, contudo, requer estudos analíticos mais aprofundados. Não podemos essencializar conclusóes e premissas a partir de uma única sondagem de opiniâo pública. 
Do ponto de vista da relaçáo dos dados com o referencial teórico utilizado no texto, as inferências apontam para uma falta de confluência entre as percepçóes da sociedade quanto à noção de educação como processo de racionalização cultural e social, como defende Max Weber. A visão é mais focada na perspectiva do pragmatismo educacional e do utilitarismo. Da mesma forma, a legislação e o planejamento estatal para o setor náo são percebidos pela opiniáo pública como portadores de uma dimensáo educativa nem como fatores de coesão social. Entretanto, tais aspectos necessitariam de aprofundamento maior, o que poderia ser objeto de outro artigo, com abordagem teórica ancorada no pragmatismo e suas implicaçóes no campo educacional, na legislaçáo e nas políticas de planejamento de longo prazo, como é o caso do PNE.

Além disso, é oportuno retomar alguns dos argumentos básicos de Hannah Arendt (1983), especialmente no que se refere à concepçáo da autora de que uma lei é algo que liga os homens entre si e se realiza não através de um ato de força, mas através de um arranjo ou um acordo mútuo. A partir dessa noção filosófica da autora, caberia questionar e problematizar os tipos de arranjos que existem na sociedade brasileira, no que se refere à educaçáo pública. Certamente, deparamo-nos com arranjos bem diferentes desse proposto pela autora, dadas as condiçóes concretas de organizaçáo social e de inserçáo dos temas educacionais na agenda pública e no debate político. A esse respeito caberia uma discussão sobre o próprio conceito de público e de como os arranjos permeiam a esfera pública, entendida como o espaço de ação comum dos cidadãos. Cumpre ressaltar aqui que a esfera pública não se limita ao campo e ao regime de açáo dos legisladores, mas também inclui os cidadáos, atores políticos responsáveis pela regulaçáo da vida política, por meio do voto e do acompanhamento das atividades legislativas.

\section{Referências}

ADRIĀO, T.; OLIVEIRA, R. P. Gestáo, financiamento e direito à educaçáo: análise da LDB e da Constituição Federal. São Paulo: Xamã, 2001.

ALMEIDA, J. R. P. História da instrução pública no Brasil (1500-1889). Brasília: Inep; São Paulo: PUC-SP, 1989.

ANDRÉ, M. Pesquisa em educação: buscando rigor e qualidade. Cadernos de Pesquisa, n. 113, p. 51-64, jul. 2001. 
ARANHA, M. L. de A. História da educaçáo. 2. ed. São Paulo: Moderna, 1996.

ARENDT, H. A condiçáo humana. Rio de Janeiro: Forense, 1983.

Entre o passado e o futuro. Sáo Paulo: Perspectiva, 2000.

. O que é política. Rio de Janeiro: Bertrand Brasil, 2004.

AVRITZER, L. Habermas e Weber: da instrumentalização da moral aos fundamentos morais da democracia. In: SOUZA, J. (Org.). A atualidade de Max Weber. Brasília: Ed. da UnB, 2000. p. 373-393.

BAUMAN, Z. Modernidade líquida. Rio de Janeiro: J. Zahar, 2001.

BOGDAN, R.; BIKLEN, S. K. Qualitative Research for Education. Boston: Allyn and Bacon, 1982.

BRASIL. Ministério da Educação. Avaliaçáo do Plano Nacional de Educaçáo 2001 - 2008. Brasília: Inep, 2009. Disponível em: <http://conae.mec.gov.br/index.php?option=com_content\&v iew=article\&id=376\&Itemid=262>. Acesso em: 25 fev. 2012.

. Presidência da República. Lei de Diretrizes e Bases da Educaçáo Nacional. Disponível em: <http://www.planalto.gov.br/ccivil_03/leis/L9394.htm>. Acesso em: 3 abr. 2012.

Câmara dos Deputados. Projeto de Lei n. 8535/2010, que institui o Plano Nacional de Educaçáo 2011-2020. Disponível em: <http://www.camara.gov.br/proposicoesWeb/fichadetramit acao?idProposicao=490116>. Acesso em: 2 abr. 2012.

BOFF, G. La concepción de laleyen Hannah Arendt. Revista Jurídica Online de Derecho Público, Gayaquil, v. 3, n. 1, p. 8-20, 2010. Disponível em: <http://www.revistajuridicaonline.com/index. php?opti on=com_content\&task=view\&id=651\&Itemid=116>. Acesso em: 3 abr. 2012.

BRIQUET, R. História da educaçáo: evoluçâo do pensamento educacional. São Paulo: Renascença, 1946.

CARDOSO, L. A. O conceito de racionalizaçáo no pensamento de Max Weber: entre a ambiguidade e dualidade. Teoria e Debate, Belo Horizonte, Universidade Federal de Minas Gerais, v. 16, n. 1, p. 256-275, jan./jun.2008.

COSSON, R. Escolas do Legislativo, escolas de democracia. Brasília: Ediçóes Câmara, 2008.

DURKHEIM, E. Nona lição: moral cívica: formas do Estado. A democracia. Liçóes de Sociologia. São Paulo: Martins Fontes, 2002. p. 137-152.

FONTOURA, A. Diretrizes e bases da educaçáo nacional: introduçáo, crítica, comentários, interpretaçáo. Rio de Janeiro: Aurora, 1968. 
LÜDKE, M. Como anda o debate sobre metodologias quantitativas e qualitativas na pesquisa em educação. Cadernos de Pesquisa, n. 64, p. 61-63, 1988.

LANGEMAN, E. C.; SHULMAN, L. S. Issues in education research: problems and possibilities. San Francisco: Jossey Bass Publishers, 1999.

MARQUES JR., A. M. Educaçáo legislativa: as escolas do Legislativo e a funçáo educativa do parlamento. E-Legis, v. 2, n. 3, p. 73-86, 2009. Disponível em: <http://bd.camara.gov.br/bd/ handle/bdcamara/2263>. Acesso em: 22 fev. 2012.

MARTINS, R. C. de R. O Poder Legislativo e as políticas públicas educacionais no período de 1995-2010. Rio de Janeiro. Tese (Doutorado em Sociologia e Ciência Política). Universidade Estadual do Rio de Janeiro, 2011.

MIGUEL, L. F. A mídia e o declínio da confiança na política. Sociologias, Porto Alegre, v. 10, n. 19, p. 250-273, jan./jun. 2008.

MORIN, E. Introducción al pensamiento complejo. Barcelona: Gedisa, 1994.

Os sete saberes necessários à educaçáo do futuro. Sáo Paulo: Cortez, 2002.

OLIVEIRA, R. de F. O FUNDEF em três dimensóes: formulaçáo, regulamentação e implementação. Belo Horizonte. Dissertação (Mestrado). Universidade Federal de Minas Gerais, 2000.

Efeitos do FUNDEF nos municípios mineiros: equidade social? In: REUNIĀO ANUAL DA ANPED, 24., 2001, Caxambu. Anais... Caxambu: ANPEd, 2001. Disponível em: <http:// www.anped.org.br/reunioes/24/T0563203073144.doc>. Acesso em: 17 dez. 2013.

PINTO, J. M. de R. A política recente de fundos para o financiamento da educaçáo e seus efeitos no pacto federativo. Educaçáo \& Sociedade, Campinas, v. 28, n. 100, p. 877-897, out. 2007. Especial.

PETITAT, A. Educaçáo difusa e relaçáo social. Educaçáo \& Realidade, Porto Alegre, Universidade Federal do Rio Grande do Sul, v. 36, n. 2, p. 365-376, maio/ago. 2011.

PIERUCCI, A. F. Secularizaçáo segundo Max Weber: da contemporânea serventia de voltarmos a acessar um velho sentido. In: SOUZA, J. (Org). A atualidade de Max Weber. Brasília: Ed. da UnB, 2000. p. 105-162.

RIBEIRO, G. W. A educaçáo legislativa é uma resposta à crise do parlamento? E-Legis, v. 4, n. 6, p. 96-103, 2011. Disponível em: <http://elegisbr.com/cefor/index.php/e-legis/article/view/68/69>. Acesso em: 22 fev. 2012.

ROMANELLI, O. de O. História da educaçáo no Brasil (1930/1973). Petrópolis: Vozes, 1978. 
SANTOS, B. de S. Democracia e participaçáo: o caso do orçamento participativo de Porto Alegre. Porto: Afrontamento, 2002a.

Democratizar a democracia: os caminhos da democracia participativa. Rio de Janeiro: Civilizaçāo Brasileira, 2002b.

SAVIANI, D. História da educação e política educacional. In: SBHE (Org.). Educaçáo no Brasil: história e historiografia. Campinas: Autores Associados, 2001. p. 11-19.

Instituiçōes escolares no Brasil: conceito e reconstruçāo histórica. In: NASCIMENTO, M.

I. M. et al. (Org.). Instituiçóes escolares no Brasil: conceito e reconstruçáo histórica. Campinas: Autores Associados, 2007. p. 3-27.

SCHLUTCHER, W. Politeísmo de valores: In: SOUSA, J. (Org.). A atualidade de Max Weber. Brasília: Ed. da UnB, 2000a. p. 13-48.

Neutralidade de valor e a ética da responsabilidade. COELHO, M. F. P. et al. (Org.).

Política, ciência e cultura em Weber. Brasília: Ed. da UnB, 2000b. p. 55-110.

SOARES, L. E. A racionalidade do "politicamente correto" ou: Weber errou porque estava certo. In: SOUSA, J. (Org.). A atualidade de Max Weber. Brasília: Ed. da UnB, 2000. p. 325-354.

SOUSA, J. A ética protestante e a ideologia do atraso brasileiro. In: . (Org.). O malandro e o protestante: a tese weberiana e a singularidade cultural brasileira. Brasília: Ed. da UnB, 1999. p. $17-54$.

. Acerca do lugar da moralidade na política: Weber, Habermas e a singularidade cultural alemã. In: SOUSA, J. (Org.). A atualidade de Max Weber. Brasília: Ed. da UnB, 2000. p. 49-90. VILALOBOS, J. E. R. Diretrizes e bases da educaçáo: ensino e liberdade. São Paulo: Edusp, 1969. WEBER, Max. A ética protestante e o espírito do capitalismo. São Paulo: Pioneira, 1989.

Economia e sociedade. Brasília: Ed. da UnB, 1999.

XAVIER, M. E. S. P.; NORONHA, O. M.; RIBEIRO, M. L. S. História da educaçáa: a escola no Brasil. Sáo Paulo: FTD, 1994. 


\section{Legislation, education and policy: social perceptions on the National Educational Bases and Guidelines Law and the National Education Plan (201 I-2020)}

\section{Abstract}

This paper studies the relationship education/legislation from the perspective of political sociology, based on the perceptions of citizens about the Law of Guidelines and Bases of National Education and the National Education Plan (2011-2020), from the following questions: what's the degree of the population's knowledge about the LDB in its 15 years of existence? What's the level of public interest and expectations in the PNE? The methodology consists in the art of survey with a questionnaire for national sample of 1,010 respondents. The theoretical scope is focused on Weber's political sociology, in which education and legislation are seen as resulting from historical Western rationality. The data indicate little popular interest in the LDB and the PNE. However, the scholling variable raises the level of knowledge/interest. The theme is recognized as nationally important, but the political overtones is just outstanding, especially when it comes to the role of legislatures in the debate over education policy. The role of the legislature is associated with warranty/inspection resources.

Keywords: Education, legislation and politics. Public educational policies. Parliament, society and education. Education and politics. 